\author{
Stanisław Chrobak* \\ Warszawa
}

\title{
Radość życia istotną cechą nauczyciela wychowawcy z perspektywy systemu prewencyjnego Jana Bosko
}

Rzeczywiste działania wychowawcze są tak różne, jak ludzie, którzy je podejmuja, oraz sytuacje, w których zachodzą. Wielość form życia, koncepcji człowieka oraz ideałów cechujących współczesne społeczeństwo jako całość w naturalny sposób wpływa także na wychowanie - na jego praktykę i teorię. Wiedza o tym, jaka jest istota człowieka i jego człowieczeństwa była i jest podstawą wiedzy o tym, jak wychowywać człowieka. Z odpowiedzi na pytania: kim jest człowiek, jakie jest jego miejsce w porządku bytów stworzonych, wynika cel, istota i przebieg procesów wychowania. Przez ideę „człowiek”, „człowieczeństwo” określamy to, kim człowiek byłby lub kim, wierzymy, mógłby być. Tego rodzaju idee o człowieku pozwalają lepiej zrozumieć, co oznacza „stawać się człowiekiem”, a więc też, jakie energie i wysiłki wychowawcze podejmować. Problematyka wychowawcza dotyczy zatem zawsze konkretnego człowieka. Wychowawca stwarza i proponuje mniej lub bardziej korzystne warunki rozwoju osoby i rozwój ten bezpośrednio umożliwia. Rola wychowawcy polega na udostępnianiu i przybliżaniu podmiotowi, który posiada swą autonomię, szeregu wartości stanowiących trwały dorobek społeczności. Treści, które są przekazywane w procesie wychowania, powinny

* Ks. dr hab. Stanisław Chrobak, prof. UKSW, jest profesorem w Wydziale Nauk Pedagogicznych Uniwersytetu Kardynała Stefana Wyszyńskiego w Warszawie. 
wprowadzać wychowanka w całość dorobku ludzkiej kultury z zachowaniem i ukazaniem hierarchii dóbr kulturowych. Współczesny wychowawca musi ponadto umieć uważnie odczytywać „znaki czasu”, czyli dostrzegać pojawiające się wartości, które pociągają młodzież. Wychowawca, wychowując, doświadcza działającej podmiotowości wychowanka. Osoba bowiem doskonali się przez uczestnictwo, które jest aktywnością, otwarciem dwustronnym: odbiorem i dawaniem ${ }^{1}$. Najpierw więc nauczyciel-wychowawca sam musi odkryć siebie, prawdę i wartości, by potem móc zaprosić ucznia-wychowanka do wejścia w dialog z wartościami, które chce mu zaproponować.

System prewencyjny, który przez samego św. Jana Bosko nie został określony teorią, koncepcją, ale właśnie „systemem”, powstał jako odpowiedź na potrzeby wychowawcze związane z konkretnym środowiskiem XIX wieku we Włoszech. Jest to synteza jego myśli pedagogicznej, wyrosłej z długiego i bogatego doświadczenia wychowawczego ${ }^{2}$, u podstaw której znajduje się idea wspierania wychowanka do wzrastania w człowieczeństwie i w działaniu - według personalistycznej inspiracji w wychowaniu - na rzecz pobudzania do osobowego sposobu życia, a więc do „wzbudzania osoby”. Taka propozycja systemowa, zaproponowana przez Jana Bosko, stanowi swoisty początek poszukiwań kompleksowości i złożoności wychowania wpisanego w rzeczywistość życia ludzkiego, w złożoność i wielorakość ludzkiej egzystencji, zarówno tej fizycznej, jak i duchowej, osadzonej w przeszłości, zachodzącej w teraźniejszości i projektującej się ku przyszłości.

${ }^{1}$ Por. J. Maritain, Dynamika wychowania, thum. A. Ziernicki, „Znak” 9 (1991), s. 28-29; G. Flores D'Arcais, Propozycja personalistyczna, w: F. Adamski (red.), Człowiek - Wychowanie - Kultura. Wybór tekstów, Wydawnictwo WAM, Kraków 1993, s. 81-83; M. Nowak, Od filozofii człowieka do filozofii wychowania, w: F. Adamski (red.), Poza kryzysem tożsamości. W kierunku pedagogiki personalistycznej, Wydawnictwo Naukowe PAT, Kraków 1993, s. 47-48. „Wychowanie potrzebuje wiedzieć przede wszystkim i w pierwszej kolejności, kim człowiek jest, jaka jest jego natura i jaką hierarchię wartości w sposób konieczny pociaga za sobą". J. Maritain, Od filozofii czlowieka do filozofii wychowania, thum. A. Ziemnicki, w: F. Adamski (red.), Człowiek - Wychowanie, s. 63-64.

2 System prewencyjny nie może być oddzielony od osoby księdza Bosko i od charakteru instytucji, w których on i jego współpracownicy działali. Z tak postawionej kwestii wynika, że fundamentalne linie działania prewencyjnego mogą być zrozumiałe tylko wówczas, gdy będą postrzegane w ścisłym związku z jego biografią, z jego temperamentem i podstawowymi wymiarami jego osobowości. Por. P. Braido, Prevenire non reprimere. Il sistema educativo di don Bosco, Roma 1999, s. 158. 


\section{System prewencyjny ks. Jana Bosko}

Ks. Jan Bosko, wychodząc od dogłębnych rozważań ówczesnych problemów społecznych, przedstawił podstawowe założenia antropologiczne, pedagogiczne, teologiczne i duszpasterskie, które wykorzystał w wychowaniu młodzieży swoich czasów. Dążył do poszukiwania takich założeń, metod, środków i form wychowania, aby pomogły mu one formować pełnego człowieka, w sensie integralnego rozwoju ludzkiego i chrześcijańskiego.

Istnieją dwa systemy - pisał Jan Bosko - jakie zawsze stosowano w wychowaniu młodzieży: prewencyjny i represyjny. [...] System prewencyjny polega na tym, że podwładnych zaznajamia się z przepisami i regulaminem zakładu, a następnie roztacza się nad nimi taką opiekę, że wychowankowie znajdują się zawsze pod czujnym okiem dyrektora lub asystentów, którzy jako kochający ojcowie przemawiają do nich, w każdej okoliczności służą im za przewodników, udzielają rad i upominają z dobrocią, co jest równoznaczne z postawieniem wychowanków w niemożności popełnienia wykroczeń. [...] System ten opiera się całkowicie na rozumie, religii i dobroci ${ }^{3}$.

W wychowaniu chodziłoby więc - według księdza Bosko - o rzeczywiste spotkanie z młodym człowiekiem, przyjęcie i zaakceptowanie go, tworzenie środowiska bogatego w wartości ludzkie i personalną relację wychowawczą. Tak rozumiane wychowanie, oferując młodemu człowiekowi podstawowe instrumenty do życia, usposabia jednocześnie do podmiotowego i odpowiedzialnego działania w każdej rzeczywistości. W tym też kontekście:

- „rozum” - zgodnie z autentyczną wizją chrześcijańskiego humanizmu - podkreśla godność osoby oraz zdolność towarzyszenia i pokierowania młodzieżą w wędrówce ku pełnemu życiu, do którego dochodzi się dzięki jasności poglądów i bezustannemu poszukiwaniu prawdy w wolności. „Rozum” oznaczający także mądrość, rozsądek, prostotę, naturalność, przyjacielskość, gotowość do dialogu i uznanie konieczności, by wychowanek w miarę swych możliwości dokonywał wyborów i podejmował decyzje, zaprasza młodych do uczestnictwa w wartościach zrozumiałych i podzielanych. „Rozum”

3 J. Bosko, System prewencyjny w wychowaniu młodzieży, w: J. Wilk (red.), Współczesny wychowawca w stylu księdza Bosko, Poligrafia Inspektoratu Towarzystwa Salezjańskiego, Lublin 1998, s. 213-214. 
zapoczątkowuje cały proces wychowania - najpierw wychowanek musi wiedzieć, co ma robić, a potem należy mu pomóc o tym pamiętać, by rozumne myślenie stało się cechą wychowanka, przekształcając się w świadomość faktycznej osobistej odpowiedzialności. Jest w całości wymiarem tego, co możemy nazwać natura ludzką. Zawiera również całą kulturę, jej dzieła i wyniki: wszystko, co zostało świadomie wypracowane;

- „religia” - wskazuje, że Jan Bosko potrafił stworzyć syntezę działalności ewangelicznej i wychowawczej. Ewangelia (głoszenie Boga, Chrystusa, zbawienia, prawdy o czasach ostatecznych...) nigdy nie była jakimś rodzajem etykiety, zbiorem rytualnych czynności czy tylko wzywaniem do przestrzegania przykazań, ale żywą prawda mobilizującą do tego, aby orędzie zbawcze stało się podstawą wychowania, było bodźcem pobudzającym rozwój, punktem odniesienia w rozwiązywaniu różnorodnych kryzysów, przenikało wszystkie dziedziny życia. W religii widział przede wszystkim drogę do serca, umysłu i duszy młodego człowieka oraz pomoc w osiaganiu pełni osobowego rozwoju człowieka. To religia motywuje człowieka do dobra, ukazuje sens jego życia i poświęcenia, zachęca do działania na rzecz dobra wspólnego. Odwoływanie się do religijności wzmacniało również świadomość rodzinności środowiska wychowawczego. Młody człowiek nie czuł się pozostawiony sam sobie, lecz towarzyszył mu wychowawca, który w wychowaniu religijnym bardzo często był pośrednikiem między rzeczywistością nadprzyrodzoną a konkretną rzeczywistością wychowanka. Idea religijności wiąże się bowiem ściśle z wcześniej omawianą zasadą rozumności, przestrzegając przed religijnością magiczną, zbyt powierzchowna, nadmiernie uczuciową oraz redukowaniem religii do nauczania reguł, zasad i definicji. Tak rozumiana zasada oznacza wiarę żywą, zakorzenioną w rzeczywistości, a nie jakąś religię spekulatywną i abstrakcyjną;

- „miłość wychowawcza” - miłość rozpatrywana w klimacie rozumu i religii oznacza przede wszystkim poszanowanie młodego człowieka. Jest to sposób bycia wyrażający sympatię, zrozumienie, współczucie, zaufanie, współuczestnictwo w życiu drugiego człowieka. Oparte na miłości wychowanie nie polega na uleganiu wszelkim zachciankom, ale na działaniu sprzyjającym asymilacji tych wartości, które stanowią podstawę bycia «dobrym chrześcijaninem i uczciwym obywatelem». Okazywana miłość to miłość ludzka, mądra, 
odrzucająca chorobliwą przesadę, sprowadzającą człowieka do roli instrumentu. Miłość wychowawcza ma prowadzić wychowanka ku pełnej dojrzałości i samodzielności. Jest uczuciem bezwarunkowym. Realizacja tak rozumianej „miłości wychowawczej” jest dla księdza Bosko w pierwszym rzędzie miłością ewangeliczną i opiera się całkowicie na słowach św. Pawła: „miłość cierpliwa jest..., wszystko znosi..., we wszystkim pokłada nadzieję..., wszystko przetrzyma..." (por. 1 Kor 13,4-7). Miłość wychowawcza to przede wszystkim świadomość odpowiedzialności i gotowość uczestniczenia w niej.

Połączone z wymogami „rozumu” wymogi „serca” (miłości wychowawczej, dobroci) i „religii” są zasadniczymi elementami systemu wychowawczego księdza Bosko. W planach edukacyjnej współpracy pamiętał o dwóch wymiarach: chrześcijanie i wszyscy ludzie dobrej woli. Szanował dobrą wolę, intelektualną uczciwość, a jednocześnie, jako ksiądz, proponował doświadczenie wiary. Podkreślał, że to dobroć serca, życzliwość buduje u wychowawcy takie podejście edukacyjne, które dociera do podmiotu i przekazuje wszystkie treści poprzez relację pełną szacunku, przyjaźni i zaangażowania. Klimat pełnego miłości, widocznego i ludzkiego oddania jest nieodzownym warunkiem relacji wychowawczej dokonującej się w spotkaniu osób.

Spotkanie, ażeby miało znaczenie wychowawcze, wymaga stałej, głębokiej uwagi, która umożliwia osobiste poznanie poszczególnych osób, a także wszystkich uwarunkowań kulturowych całej grupy. Chodzi tu o rozumna, życzliwą uwage, która pozwoli odczytać pragnienia, sposoby wartościowania, uwarunkowania, sytuacje życiowe, wzorce środowiskowe, napięcia, żądania i zbiorowe postulaty. Chodzi też o to, by dostrzegać pilną potrzebę formacji sumienia zmysłu rodzinnego, społecznego i politycznego, dojrzewania do miłości i chrześcijańskiego poglądu na płciowość, zdolności krytycznej oceny i właściwej podatności na przemiany związane z wiekiem, rozwojem umysłowości, za-

${ }^{4} \mathrm{Na}$ ten temat zobacz m.in.: L. Cian, System zapobiegawczy św. Jana Bosko i charakterystyczne rysy jego stylu, tłum. M. Gabryel, Wydawnictwo Salezjańskie, Warszawa 1986; C. Nanni (red.), Il sistema preventivo e l'educazione dei giovani, LAS, Roma 1989; L. Cian, Wychowanie w duchu Księdza Bosko, thum. I. Gutewicz, Wydawnictwo Salezjańskie, Warszawa 1990; R. Weinschenk, Podstawy pedagogiki Księdza Bosko, thum. J. Jurczyński, Wydawnictwo Salezjańskie, Warszawa 1996; C. Bissoli, Jan Paweł II o systemie wychowawczym księdza Bosko, thum. K. Misiaszek, Wydawnictwo Salezjańskie, Warszawa 2001. 
wsze pamiętając, że młodość nie jest okresem przejściowym, lecz konkretnym czasem łaski, danym dla kształtowania osobowości ${ }^{5}$.

Te same wiadomości znaczą więcej w kształtowaniu ucznia, jeżeli są przyswojone w kontekście relacji osobowych, szczerej wzajemności, zgodnych postaw, stylu bycia na co dzień. W konsekwencji ukształtowana w ten sposób wspólnota wychowująca staje się prawdziwym środowiskiem życiowym.

Wzajemne oddziaływanie wychowawcze trzeba widzieć jako szczególną sytuację międzyosobową, rozumianą jako „obecność” osoby oddanej całkowicie dla dobra drugiego. Wzajemne zaufanie we wspólnocie jest tym silniejsze, im bardziej wspólne, podzielane przez wszystkich są podstawowe wartości. Ksiądz Bosko nigdy nie pracował w izolacji i w samotności „dla” młodzieży. Zawsze działał we współpracy i razem z młodzieżą, a najwięcej uwagi poświęcał młodzieży pod wieloma względami najuboższej. We wspólnocie tworzył taki klimat, który pomagał w pozytywnym wzajemnym oddziaływaniu na siebie jej członków. Od wychowawców wymagał starannego przygotowania, zawodowej kompetencji w dziedzinie dydaktyki i pedagogii. Punktem wyjścia dla księdza Bosko było konkretne, „to” właśnie, a nie inne dziecko wraz ze swymi potrzebami, radościami i nadziejami. W pracy pedagogicznej oznaczało to interesować się wychowankiem, starać się nawiązać z nim dialog, zrozumieć jego uczucia, dostrzec jego prawdziwe życie. Podkreślał, że prawdziwy i trwały rozwój każdego człowieka ma źródło w jego własnym sercu, życiu i wolności. Czynił wszystko, by środowisko wychowawcze pozwalało na integrację kultury i wiary, rozróżniając, ale nie rozdzielając tych sfer działania. Postulował, by wychowywać „uczciwych obywateli i dobrych chrześcijan”, inicjując moralne, naukowe i obywatelskie wychowanie młodzieży ${ }^{6}$. To stawanie się uczciwym obywatelem i dobrym chrześcijaninem nie może się dokonać w życiu młodzieży bez pomocnej obecności wychowawczej.

5 Jan Paweł II, Iuvenum patris. List Ojca Świętego Jana Pawła II do księdza Egidio Vigano przetożonego Generalnego Towarzystwa św. Franciszka Salezego w setna rocznice śmierci św. Jana Bosko, Rzym 1988, 12.

${ }^{6}$ Por. L. Cian, Wychowanie, s. 221-224; R. Weinschenk, dz. cyt., s. 105-109. „Potrzeba nam tej radości życia, którą mają młodzi. W tej radości życia jest coś z tej pierwotnej radości, jaką miał Bóg stwarzając człowieka. Młodzi mają właśnie w sobie tę radość. Jest ona w każdym miejscu ta sama, a równocześnie inna, oryginalna. Potrafią ją po swojemu wypowiedzieć". Jan Paweł II, Przekroczyć próg nadziei, Redakcja Wydawnictw Katolickiego Uniwersytetu Lubelskiego, Lublin 1994, s. 104. 


\section{Konieczność wychowawcy}

Obecność wychowawcy wśród młodzieży, uczestnictwo w jej życiu jest integralną częścią procesu wychowania. Ksiądz Bosko, ilekroć mówi o wychowaniu, ma zawsze na myśli kontakt międzyosobowy, który znaczy więcej niż przypadkowe spotkanie. Nie ma jednego konkretnego wzoru wychowawcy. „W każdym chłopcu, nawet tym najgorszym, jest jakieś miejsce wrażliwe na dobro. Pierwszym i zasadniczym obowiązkiem wychowawcy jest właśnie odkrycie tego miejsca, tej wrażliwej struny jego serca, aby ją następnie wykorzystać w pracy wychowawczej"7. Tak rozumiana sylwetka współczesnego wychowawcy wymaga ,tworzenia, a nie odtwarzania własnego sposobu bycia z uczniem. Ten obowiązek jest konstytutywną cechą zawodu nauczyciela i sprawia, że przygotowanie do tego zawodu jest zawsze prowizoryczne, wciąż wymagające zmian i uzupełnień". . Refleksja nad działaniem i w czasie jego trwania umożliwia nauczycielowi (wychowawcy) krytyczną i twórczą zmianę. Praktyka zawodowa nauczyciela-wychowawcy musi zatem uwzględniać wiele kontekstów oddziaływania na wychowanka, między innymi bezpośredniość, unikatowość i niepowtarzalność każdej sytuacji szkolnej, promowanie takich cech edukacyjnego działania, jak: odpowiedzialność, współdziałanie, współpraca, otwarte komunikowanie się, rozumienie sensu planowanych i już dokonujących się zmian w uspołecznianiu i wychowaniu obywatelskim wychowanka. Istotą wychowania jest pomoc w rozwoju drugiego człowieka, dlatego należy stawiać wysokie wymagania zarówno wobec wychowanka, jak i wobec wychowawcy ${ }^{9}$, ZZ pewnością łatwiej jest się złościć - podkreśla ks. Bosko - niż być cierpliwym; grozić dziecku niż je przekonywać; powiedziałbym, wygodniej jest dla naszego

7 S. Szmidt (red.), Pozwól gwizdać szpakom. Wybór myśli i wskazań św. Jana Bosko dla młodzieży i starszych, Wydawnictwo Salezjańskie, Warszawa 1998, s. 41-42.

${ }^{8}$ R. Kwaśnica, Wprowadzenie do myślenia o wspomaganiu nauczycieli w rozwoju, „Studia Pedagogiczne" 61 (1995), s. 13.

${ }^{9}$ Por. J. Rutkowiak, Edukacyjna świadomość nauczycieli: intelektualizacja pracy nauczycielskiej jako wyzwanie czasu transmisji, w: tenże (red.), Odmiany myślenia o edukacji, Oficyna Wydawnicza „Impuls”, Kraków 1995, s. 299-301; Z. Kwieciński, Demokracja jako zadanie edukacyjne i problem pedagogiki, w: B. Śliwerski (red.), Pedagogika alternatywna, Oficyna Wydawnicza „Impuls”, Kraków 2000, s. 36. 
braku cierpliwości i pychy karać tych, którzy stawiają opór, niż poprawiać ich poprzez wytrwałe i życzliwe znoszenie ich"

Dynamiczna, dojrzała, w pełni ukształtowana osoba wychowawcy, ujawniającego własną filozofię życiową i wybory wartości - ich hierarchię i uzasadnienie - wiarygodnego w ich odpowiedzialnej realizacji, jest warunkiem rozwoju osoby wychowanka. W nauczaniu i wychowaniu nauczyciel wykorzystuje swoją wiedzę oraz własną, niepowtarzalną osobowość. Sam przeto musi być wzorem nie tylko postaw poznawczych, kwalifikacji rzeczowych, lecz także etycznych. „Kształcić człowieka” może tylko człowiek odpowiedzialny i przekonany o celowości tego, co robi. Taki, który wierzy, że hierarchia wartości, wrażliwość, wyobraźnia i poszukujący umysł są ważniejsze od ilości wtłoczonej wiedzy. Dostrzeżenie przekonującej i wyrazistej propozycji wartości pociąga za sobą jej weryfikację, czyli obserwację, mającą wykazać, czy wydarzenie, które nadało sens życiu mistrza, jest też w stanie dać sens i smak naszemu własnemu życiu.

Nie jest prawda, że szacunek dla wolnego wyboru ucznia oznacza brak jakiejkolwiek propozycji typu aksjologicznego. Bez ukazania świata wartości nie ma prawdziwego wychowania. Nie jest też prawdą, że trzeba odmienne, niekiedy przeciwstawne, systemy wartości przedstawiać tak, jakby wszystkie były jednakowo ważne i możliwe do przyjęcia. Nauczyciel jawi się wówczas jako ktoś, kto nie ma własnych poglądów i przekonań, a więc nie zasługuje na wiarygodność i zaufanie ${ }^{11}$.

Wychowanie domaga się żywego świadectwa człowieczeństwa. „Wychowuje ten, kto konkretnie i osobiście zaświadcza wobec wychowanka o tym, że można się wszechstronnie spełnić, gdy przeżywa się rzeczywistość zgodnie z jej wszystkimi współczynnikami. [...] Wychowanie otwiera wychowanka na jak największą kreatywność"12. Uznanie roli świadków i mistrzów w życiu osób i społeczeństw wymaga zgody na widzenie świata i innych ludzi poprzez pryzmat pozytywnego znaczenia „drugiego” we własnym życiu, począwszy od przyjęcia, że w realnym świecie żyli i żyją pozytywni

${ }_{10}$ T. Bosko, Złote myśli Księdza Bosko, tłum. A. Lis, Wydawnictwo Salezjańskie, Warszawa 2002, s. 150.

11 J. Nagórny, Posłannictwo szkoły - posłannictwo nauczyciela, „Cywilizacja. O nauce, moralności, sztuce i religii" 14 (2005), s. 22.

12 A. Scola, Przygoda wychowawcza w społeczeństwie okresu przejściowego, thum. P. Borkowski, „Społeczeństwo” 2 (2008), s. 228-229. 
„inni”; zgody na to, że „drugi” może być i jest kimś pozytywnie znaczącym, kimś, kto niesie w sobie pozytywne cele i wartości, prowadzi drogą prawdy i świadectwa. Relacja mistrza i ucznia jest zawsze relacją osobową. Z istoty pełnienia roli społecznej wynika, że dana osoba jest wtedy pewnym przykładem, a idealne o niej wyobrażenia łączą się z oczekiwaniem, iż będzie mistrzem. Proces wychowawczy przebiega zawsze tą samą drogą: „mistrz”, głoszone przez niego wartości, obserwacja i weryfikacja. Jeśli ta ostatnia wypada pomyślnie, wartość odradza się w sercu ucznia ${ }^{13}$. „Mistrz to ktoś, za kim chcemy podążać, kto nas fascynuje, pociaga, inspiruje. Mistrz jest potrzebny wówczas, gdy samemu nie daje się rady, gdy albo brak odwagi, albo jeszcze umiejętności, aby kroczyć samodzielnie. W swoim uczeniu się człowiek potrzebuje mistrzów, czyli osób, które może naśladować, po to, aby następnie zrobić daną rzecz samodzielnie"14. Mistrz przekazuje to, co jest treścią jego własnego rozwoju, dokonującego się poprzez wejrzenie w siebie, we własne wartości, priorytety, działania, a także mądrość. Pojęcia „mistrz” czy „uczeń" nawiązują nie tyle do hierarchii i dystansu, ile do wspólnoty. Mimo odrębnych statusów i hierarchicznej współzależności, mimo tego, że to mistrz prowadzi grę oraz usiłuje doskonalić ucznia, samym swoim istnieniem go stymuluje. Daje z siebie wszystko, by sprostać jego oczekiwaniom. Mistrz pomaga uczniowi odkryć własny potencjał i możliwości twórcze.

Takie rozumienie relacji wychowawczej pozwala wychowankowi i wychowawcy na wymianę swoich najgłębszych przeżyć, potrzeb i pragnień, tworzy emocjonalne zaangażowanie. Tym samym kierunek procesu wychowawczego jest nie jedno- lecz wielostronny, obejmujący dialog, wolność, autentyczność powiązaną z konkretnym usytuowaniem. Przesadnie neutral-

${ }_{13}$ Por. Wołanie o mistrza. Z księdzem Januszem Tarnowskim rozmawiaja Elżbieta Osewska i Tomasz Ochinowski, „Więź” 12 (1995), s. 87-88; K. Olbrycht, O roli przykładu, wzoru, autorytetu i mistrza w wychowaniu osobowym, Wydawnictwo Adam Marszałek, Torun 2007, s. 17-25. „Bardzo istotny dla rozważanej problematyki jest pogląd, że mistrz zachęca do myślenia i działania, pokazuje ważne problemy i jest drogowskazem w zakresie wartości, a zarazem potrafi przekazać część swej energii duchowej. [...] Przekazywanie energii duchowej następuje za sprawą przyzwolenia dziecku/wychowankowi/uczniowi na czerpanie z sił moralnych i intelektualnych wychowawcy/nauczyciela/mistrza, który odsłania wiele tajemnic właśnie tylko jemu”. U. Ostrowska, Fenomen spotkania w wychowaniu, „Edukacja. Studia. Badania. Innowacje" 4 (2007), s. 13-14.

${ }_{14}$ T. Bauman, Mistrzowie i szkoły myślenia w uniwersytecie, w: E. Rodziewicz, K. Rzedzicka, E. Zalewska (red.), Gdańskie rodowody pedagogiczne. Geneza, kontynuacje, inspiracje, przemieszczenia znaczeń wychowawczych, Wydawnictwo Uniwersytetu Gdańskiego, Gdańsk 2004, s. 73. 
ny nauczyciel-wychowawca, nieczytelny w swoich postawach i światopoglądzie, nie motywuje wychowanków do własnych poszukiwań i wyborów. Natomiast jego uczciwość w dialogu z wychowankiem, tolerancja, szacunek dla jego podmiotowości często mogą zdecydować o przebiegu kształtowania się systemu wartości wychowanka. „Tym, co daje uczniowi mistrz, jest poznanie, świadomość ja, odwaga stawiania trudnych pytań (kim jestem?, dokąd zmierzam?). Mówiąc językiem współczesnej psychologii, mistrz wyposaża ucznia w podstawy tożsamości. [...] Wskazywanie drogi przez mistrza nie ma charakteru instrumentalnego, nie jest zawładaniem, wyobcowywaniem czy manipulowaniem osobą wychowanka, ucznia"15. Ksiądz Bosko, budując system prewencyjny na podstawie doświadczeń swego życia, wiedział, że należy stworzyć system wychowania integralnego, poprzez który młody człowiek otrzyma pomoc w rozwoju naturalnym, kulturowym i duchowym. Proponuje wychowanie, które zarazem jest twórcze i wierne, w którym wychowawca dochowuje wierności tradycji, a równocześnie jest wrażliwy na potrzeby współczesnej młodzieży.

\section{Radość życia w wychowaniu}

O księdzu Bosko mówi się jako o jednym z największych współczesnych wychowawców, który jako praktyk i człowiek czynu opracował ponadczasową metodę wychowawczą, opartą na trójmianie „rozum - religia miłość” i którą można zdefiniować poprzez jego krótkie zdanie: „Wychowanie jest sprawą serca”. Chodzi tu o codzienna postawę, która zakłada dyspozycyjność, zdrowe zasady i odpowiedni sposób postępowania. Ksiądz Bosko podkreślał wielokrotnie: „moja metoda wychowawcza polega na tym, że daje się chłopcom większą wolność robienia tego, co im się najbardziej podoba. Chodzi mianowicie o to, by odkryć w nich zarodki uzdolnień i dobrych cech charakteru, i starać się następnie je rozwijać. Dlatego kieruję się zasadą, aby każdy robił z radością to, co potrafi, a moi chłopcy współpracują

${ }_{15}$ M. Karkowska, Literackie obrazy uczeń - mistrz w wychowaniu, w: S. Sztobryn, B. Śliwerski (red.), Idee pedagogiki filozoficznej, Wydawnictwo Uniwersytetu Łódzkiego, Łódź 2003, s. 142. „Mistrzem dla mnie jest ktoś, kto pomaga mi odkryć moje powołanie i towarzyszy w drodze u jej początku. Potem - każe mi iść dalej samemu. [...] Mistrz nie wiąże ucznia ze sobą, nie zniewala, nie uzależnia. Niepotrzebną już więź przecina i uczeń - naturalną rzeczy koleją - rozstaje się z mistrzem, odchodzi. Musi odejść!”. P. Taranczewski, Porzuceni mistrzowie, ,Znak” 3 (2007), s. 63. 
ze mną nie tylko z zapałem, ale przede wszystkim z miłością" ${ }^{16}$. Wszystko to wymaga prawdziwego bycia do dyspozycji młodzieży, szczerej życzliwości i umiejętności dialogu. Prawdziwy wychowawca uczestniczy więc w życiu młodzieży, interesuje się jej problemami, stara się poznać jej zapatrywania, uczestniczy w jej życiu sportowym i kulturalnym, w jej rozmowach. W takim klimacie ,pedagogicznej obecności” znamienne są słowa Jana Bosko, będące kwintesencją radości wychowywania: „Jest mi tu dobrze z wami, przebywanie z wami to moje życie" 17 .

Poszukując odpowiedzi na pytanie, co jest istotą wychowania, mamy na uwadze nie tylko wiedzę teoretyczną o tym fenomenie, zawierającą jego uzasadnienie czysto zewnętrzne, tkwiące w określonych poglądach, doktrynach, podejściach czy stanowiskach, ale i sferę praktyczna, jego codzienny wymiar, wpisujący się w dzieje i biografie jednostek ludzkich, pokoleń, kultur i społeczeństw. Zatem zainteresowanie się ,żywym konkretem” kieruje nas na rzeczywistość wychowania i stanowi punkt wyjścia w poszukiwaniu odpowiedzi na pytanie o wychowanie i jego istotę oraz o konkretne (realne) możliwości pomocy człowiekowi w stawaniu się sobą.

Proces wychowawczy zakłada mocną obecność wychowawcy, posiadanie trudnej sztuki, w której będzie pasja, pragnienie, radość; ta pasja wychowawcza, dzięki której wychowawca i zwłaszcza rodzice uczestniczą w odnowie życia i nowym stworzeniu [...]. To właśnie jest wieczna droga autentycznej humanistycznej pedagogii, którą wyraża powiedzenie: stań się, kim jesteś, i niech się rozwija ta najwznioślejsza cząstka, która jest w tobie ${ }^{18}$.

Takie życie prowadzi do ciaghego osiągania pełni człowieczeństwa i stawania się „,bardziej człowiekiem”. Jak podkreśla J. Tarnowski,

skoro człowiekiem jest zarówno wychowawca jak i wychowanek, proces zaś pedagogiczny zmierza do urzeczywistnienia człowieczeństwa, nasuwa się wniosek, że właściwie wychowują się oni wzajemnie. Wychowawcy przecież nie przysługuje doskonałość z racji pełnionej przez niego roli. Oczywiście po-

16 S. Szmidt (red.), dz. cyt., s. 39-40.

${ }_{17}$ Memorie biografiche di don Givanni Bosco, IV, 654, cyt. za: L. Cian, Wychowanie, s. 196.

18 V. Possenti, Wychowanie osoby wyzwaniem kulturowym, tłum. T. Żeleźnik, „Społeczeństwo" 2 (2008), s. 220-221. 
nosi przede wszystkim odpowiedzialność, ale też wiele może i powinien nauczyć się od dziecka ${ }^{19}$.

Bycie wychowawcą ma szczególny wymiar. Z jednej strony jest on postrzegany jako organizator i kierownik procesów edukacyjnych, z drugiej zaś jego działalność oparta jest na specyficznej formie kontaktu międzypodmiotowego. W swoich działaniach przyjmuje na siebie wszystkie konsekwencje, jakie wiążą się z ich realizacją, jak również jest odpowiedzialny za skutki tegoż działania. Odpowiedzialność wychowawcy wynika zatem nie tylko z cech jego charakteru, ale i z miłości rozumianej jako autentyczna forma więzi $\mathrm{z}$ drugą osobą.

Wychowywać to rzecz piękna: kiedy się naprawdę kocha, przeżywa się radość z przebywania z tymi, których się kocha, radość z ich wzrostu, stawania się ludźmi dorosłymi albo przynajmniej z ich trudnej walki, aby się nimi stać, by żyć, by się zrealizować: są to sekretne radości wychowawcy, życie wśród młodych ludzi kompensuje i nadaje sens umieraniu sobie samemu, zawartemu w każdej autentycznej pracy wychowawczej ${ }^{20}$.

Radość jest w człowieku, w nim się rodzi, rozwija lub gaśnie.

Człowiek afirmuje życie, napełnia go radość z egzystencji, ufa, że znajdzie się droga wyjścia nawet w sytuacji beznadziejnej. „Radość pojawia się w związku z jakimś wydarzeniem, spotkaniem, jakimś szczególnym doświadczeniem w ramach mojego odniesienia do świata, chociaż sam jej nie wywołałem pozytywnym aktem woli, a to zabarwienie uczuciowe we mnie nie podlega bynajmniej mojej dyspozycji. [...] Jest znakiem afirmacji samego siebie, dobrowolnym i pełnym zadowolenia «tak» życiu" ${ }^{21}$. Optymizm, radość i wiara w siebie pozwalają na podtrzymywanie realizacji powziętego planu i decyzji. Radość wzmacnia, budzi energię i zapał do pracy nad sobą. Przymioty radości, w swej naturze ekspresywne i dynamiczne, uprzyjemniają działanie i mobilizują całą sferę wychowawczą. Zdolność do radości rodzi poczucie sensu życia przez nadawanie znaczenia zwyczajnym zdarzeniom.

19 J. Tarnowski, Człowiek - dialog - wychowanie. Zarys chrześcijańskiej pedagogiki personalno-egzystencjalnej, „Znak” 9 (1991) s. 69.

${ }^{20}$ G. Gatti, Tradycja wychowawcza ks. Bosko dzisiaj: konieczność wychowawcy, w: J. Wilk (red.), dz. cyt., s. 81.

${ }^{21}$ L. Lavaud, Radość petna nadziei, thum. L. Balter, „Communio” 6 (2004), s. 11-12. 
Przynależność do grupy, w której panuje radosna atmosfera, może sprzyjać przełamywaniu barier społecznych, zmniejszać poczucie zagrożenia i lęku, nasilać atrakcyjność współdziałania, rozwijać spontaniczność i autentyczność w porozumieniu międzyludzkim, rozwijać postawy autokreacyjne. Indywidualne doświadczenie radości zostaje udoskonalone i wzmocnione odmienną wrażliwością drugiego człowieka. Radość życia jest istotnym czynnikiem nie tylko sensotwórczym, ale i osobotwórczym ${ }^{22}$.

$\mathrm{Na}$ określenie poprawnej relacji pomiędzy wychowawcami i wychowankami ksiądz Bosko lubił używać terminu familiarità (zażyłość, przyjaźń). Długoletnie doświadczenie przekonało go, że bez tej zażyłości nie można okazać miłości, a bez tego trudno o wzbudzenie zaufania, które jest niezbędnym warunkiem skuteczności pracy wychowawczej. Ogół celów, które należy osiagnaçć, program, wskazania metodologiczne stają się konkretne, jeśli są nacechowane szczerym «duchem rodzinnym», tzn. jeśli będą przeżywane w środowisku radosnym, pogodnym i mobilizującym ${ }^{23}$.

Radość życia, stanowiąc siły napędowe wszelkich wysiłków wychowawczych, sprzyja budowaniu właściwego klimatu wychowawczego.

Pełna afirmacja siebie samego, dokonująca się w autentycznym przeżyciu radości, obejmuje zarówno teraźniejszość, jak i przyszłość. Radość życia niezmiennie współtworzy naturę ludzką, pozostając w organicznej jedności ze smutkiem, przygnębieniem, bólem i cierpieniem. Radość nie jest ucieczką od teraźniejszości. U podłoża radosnego przeżywania życia znajduje się również doświadczenie wiary. Życie chrześcijanina nie byłoby pełne i autentyczne, gdyby nie uczestniczyło w radości samego Chrystusa, a za Jego pośrednictwem - w radości Boga, który jest Miłością. Przepełniony Bożą radością chrześcijanin nie staje się tym samym mniej uważny na życie codzienne, na problemy i dramaty, w jakich uczestniczy. „W swoim rozwoju chrześcijańska radość zdąża bowiem nieodzownie do ogarnięcia i przeniknięcia tego wszystkiego, z czym się spotyka. [...] W człowieku nie da się nigdy zamazać, zatuszować ani tym bardziej zagłuszyć za pomocą jakiejś

22 Por. A. Żywczok, Wychowanie do radości życia, Wydawnictwo Akademickie „Żak”, Warszawa 2004, s. 87-96.

23 Jan Paweł II, Iuvenum, 12. Jan Bosko często powtarzał: „Jestem pewny sukcesu mojej pracy jedynie wtedy, gdy widzę chłopców w czasie rekreacji pełnych radości i energii do zabawy". Memorie biografiche di don Givanni Bosco, VI, cyt. za: R. Weinschenk, dz. cyt., s. 141. 
przejściowej, efemerycznej sytuacji zadowolenia, jego głębokiej potrzeby autentycznej i trwałej radości"24.

Namysł nad ludzką radością istnienia nie służy jedynie poznaniu, czym ona jest. Doświadczenie radości życia jest owocem indywidualnego wysiłku.

Wychowawca więc powinien mieć wyraźną świadomość celu ostatecznego, ponieważ w sztuce wychowania cele pełnią funkcję decydującą. Ich widzenie niepełne lub błędne, bądź też zapominanie o nich jest dowodem niekompetencji i staje się przyczyną jednostronności i wypaczeń. [...] Jego (Jana Bosko) niezwykły sekret polegał na tym, że nie zawiódł nigdy najgłębszych pragnień młodzieży (chęci życia, pragnienia miłości, otwarcia duszy, radości, wolności, nastawienia ku przyszłości), a równocześnie prowadził ją stopniowo i w sposób konkretny do przekonania, że tylko przez życie w łasce, to jest w przyjaźni z Chrystusem, w pełni realizują się autentyczne ideały ${ }^{25}$.

Jan Bosko wiedział, że radość jest nie tylko osiagnięciem pewnego stanu psychicznego, ale budowaniem własnego człowieczeństwa. Postawa radości życia może się rozwijać i ewoluować w pogodny sposób bycia czy nawet styl życia. Obok miłości, prawdy i wolności radość jest wartością nadającą sens życiu i stanowiącą o najgłębszej istocie osoby ludzkiej. Prawdziwa radość nie przeczy prawdzie. Radość wzmacnia, budzi energię i zapał do pracy nad sobą, tworzy sprzyjający wychowaniu klimat wspólnoty i porozumienia.

\section{Joy of Life as an Important Quality of a Teacher-Tutor from a Perspective of John Bosco's Preventive System (Summary)}

Educational problems always refer to an individual person. Don Bosco is said to be one of the greatest contemporary tutors who, as a practitioner and a man of action, developed a timeless educational method based on the trinomial "reason -

${ }^{24}$ A. Cazzago, Radość Chrystusa i chrześcijanina, tłum. L. Balter, „Communio” 6 (2004), s. 50-51. „Chrześcijaństwo jest przekonane, iż cały wszechświat stworzony przez Boga jest przezeń zachowywany w istnieniu pozytywnie i bezpośrednio (creatio continua), a nie w sposób uboczny. Radość stworzenia płynie wobec tego z faktu, że świat jest ustawicznie stwarzany, dzięki stwórczej obecności (immanencji) Boga w świecie, który sprawia, że wszystko, co stworzone, jest dobre”. M. Kowalczyk, Teologiczny wymiar radości chrześcijańskiej, „Communio" 6 (2004), s. 31-32.

25 Jan Paweł II, Iuvenum, 16. 
religion - loving/kindness" and which can be defined by his short slogan: "Education is a matter of the heart". Educators participate in teenagers' lives; they are interested in their problems, try to become familiar with their opinions and they participate in their sports and cultural life, as well as, in their conversations. In this atmosphere of "pedagogical presence", John Bosco's words are significant and they are the essence of educational joy: "I feel good with you, being here with you is my life". An individual experience of joy is improved and stronger thanks to a different sensitivity of other person. The joy of life is an important factor which is not only sense-creative but also person-creative. The joy is not an escape from the present time. Being a driving force for all educational efforts, it supports the creation of appropriate educational atmosphere.

Keywords: education, preventive system, reason, religion, educational love, joy

\section{Radość życia istotną cechą nauczyciela wychowawcy z perspektywy systemu prewencyjnego Jana Bosko (Streszczenie)}

Problematyka wychowawcza dotyczy zawsze konkretnego człowieka. O księdzu Bosko mówi się jako o jednym z największych współczesnych wychowawców, który jako praktyk i człowiek czynu opracował ponadczasową metodę wychowawczą, opartą na trójmianie „rozum - religia - miłość” i którą można zdefiniować poprzez jego krótkie zdanie: „Wychowanie jest sprawą serca”. Wychowawca uczestniczy więc w życiu młodzieży, interesuje się jej problemami, stara się poznać jej zapatrywania, uczestniczy w jej życiu sportowym i kulturalnym, w jej rozmowach. W takim klimacie ,pedagogicznej obecności” znamienne są słowa Jana Bosko, będące kwintesencją radości wychowywania: „Jest mi tu dobrze z wami, przebywanie z wami to moje życie". Indywidualne doświadczenie radości zostaje udoskonalone i wzmocnione odmienną wrażliwością na drugiego człowieka. Radość życia jest istotnym czynnikiem nie tylko sensotwórczym, ale i osobotwórczym. Radość nie jest ucieczką od teraźniejszości. Stanowiąc siły napędowe wszelkich wysiłków wychowawczych, sprzyja budowaniu właściwego klimatu wychowawczego.

Słowa kluczowe: wychowanie, system prewencyjny, rozum, religia, miłość wychowawcza, radość 
